\title{
Neoliberalism as Religion: \\ Sacralization of the Market and Post-Truth Politics
}

\author{
Luca Mavelli \\ I.mavelli@kent.ac.uk \\ University of Kent
}

\section{Forthcoming in International Political Sociology}

\begin{abstract}
In the aftermath of the 2008 financial crisis, depictions of neoliberalism as religion, system of belief, and "kind of faith" have multiplied in an attempt to explain neoliberalism's remarkable power and resilience. These accounts, however, have remained largely impressionistic. In this article, I interrogate the meanings, implications, and value of conceptualizing neoliberalism as religion and advance two main claims. First, the power of neoliberalism stems from being a rationality of government that continuously evokes religious meanings and significations. Neoliberalism displaces and redraws the boundary between secular and religious, and appropriates an aura of sacredness while concealing itself behind an authoritative secular rational façade. Second, one of the outcomes of the neoliberal "sacralization" of the market has been the emergence of so-called "post-truth politics." The latter, I contend, can be conceptualized as a neoliberal "truth market" of news production, circulation, and consumption that is governed simultaneously by logics of commodification and belief. This analysis aims to contribute to existing debates on secularization, on neoliberalism's resilience, and on post-truth politics by showing their interconnectedness through a critical approach that focuses on the disarticulation, rearticulation, and deployment of the categories of the secular/profane and sacred/religious in neoliberal regimes of power and knowledge.
\end{abstract}




\section{Introduction}

Speaking in the early days of the 2008 financial crisis, renowned historian Eric Hobsbawm observed how "a sort of theological free-market ideology" had dominated the thirty years prior to the crisis (cited in Peck, Theodore, and Brenner 2010, 99). Shortly afterwards, economist and Nobel Prize winner Joseph Stiglitz $(2009,346)$ offered a similar remark: "[f]rom a historical point of view, for a quarter of century the prevailing religion of the West has been market fundamentalism." The remarkable resilience of neoliberalism - its capacity to survive the crisis and thrive despite being widely regarded as the main culprit for the worst recession since the Great Depression - has prompted a multiplication of depictions of neoliberalism as religion, system of belief, "kind of faith" (Graeber and Piketty 2014) and "theology disguised as social science" (Petrella 2008, 127). These characterizations, however, have remained largely impressionistic. They have mostly emphasized that although the 2008 financial crisis may "have represented a kind of theological crisis for the neoliberal belief system" (Peck, Theodore and Brenner 2010, 99), it has not undermined a widespread dogmatic belief in neoliberal "market fundamentalism."

Indeed, the initial expectation that a crisis of this magnitude would engender a "post-neoliberal" shift has progressively vanished (Konings 2016, 268; see also Crouch 2011; Harvey 2010; Schmidt and Thatcher 2013). Governments' responses to the crisis have often consisted of more neoliberal policies, such as austerity measures and welfare cuts, bailing out with public money the financial actors responsible for the crisis, and encouraging the further penetration of mechanisms of competition, privatization, commodification, and neoliberal re-regulation in new social and political domains. The almost unchallenged authority of neoliberalism is even more puzzling given that, as Mitchell Dean $(2014,161)$ recently observed, neoliberalism is progressively casting off "its supposition of economic equilibrium and its triumphalist narratives of the welfare-generating properties of the omniscient market and simply seeks to fashion ways to make individuals, communities, systems and organizations fit for rigors of the catastrophe yet to come." Hence, is it the case that neoliberalism - whether understood as a rationality of government, economic theory, or political philosophy - has acquired an almost "sacred status" to the effect that it now commands a quasi-religious authority, even despite its incapacity to deliver prosperity and growth?

This article interrogates the meanings and implications of conceptualizing neoliberalism as religion. It argues that this approach can contribute to a better understanding of neoliberalism's resilience and growing capacity to shape not only "the economy" and "the market," but also social and political domains. In particular, the article aims to show how one of the outcomes of the neoliberal "sacralization" of the market has been a totalizing process of commodification that has resulted, 
among other things, in the emergence of the so-called "post-truth politics" or "post-fact society." Posttruth politics, I will argue, is the instantiation of a sacralized neoliberal "truth market" that posits ignorance and unreserved belief in the market as necessary conditions of possibility for freedom. This case is particularly interesting for two reasons. First, it makes it possible to investigate the meanings, boundaries, and manifestations of the secular and the religious in modern societies beyond their conventional understandings - hence the focus on the domain of news production, circulation, and consumption, which is widely regarded as secular. Second, this analysis aims to advance existing research on neoliberalism by showing how its rationalities of government entail not just logics of competition and commodification, but also belief.

In order to advance these arguments, we must begin with a reflection on what is generally meant by "religion" in the utterance "neoliberalism is a form of religion." This, in turn, requires interrogating the meaning of secularism given the mutually constructed nature of the "constitutively interrelated domains" of the secular and the religious (Scherer 2013, 8; see also Casanova 1994, 20; McCutcheon 2007; Hurd 2004, 238 and 2017). For philosopher Giorgio Agamben (2011), there are two possible ways of understanding secularism. A first way draws on Max Weber's well-known "thesis about the secularization of Puritan asceticism in the capitalist ethics of work" (Agamben 2011, 3).

According to Weber (2003 [1905]), the emergence of modern capitalism was the product of a distinctively religious calling grounded in the Calvinist idea of predestination. Yet, the advancement of scientific rationalism increasingly pushed religion into the realm of the irrational. The original religious inspiration for the development of capitalism was eventually replaced by scientific bureaucratic rationality (Weber 1991 [1915], 281). From this perspective, secularization is a process of replacement: secular forms of rationalization progressively replaced religious ones. Secularism is a condition characterized by the public triumph of science, reason, and critique over belief, emotions, and dogma, which are confined to the private sphere. This view implicitly informs the quotes in the opening paragraph of this article. They frame religion in the form of neoliberalism as the expression of irrational beliefs and uncritical thinking and suggest that its public presence is a glitch, a bug, a malfunction in the rational secular path of modernity.

According to Agamben $(2011,4)$, a different and more sophisticated approach consists in understanding the process of secularization not as a "concept," but as a "signature" [segnatura]. A signature is "something that in a sign or concept marks and exceeds such a sign or concept referring it back to a determinate interpretation or field, without for this reason leaving the semiotic to constitute a new meaning or a new concept" (Agamben 2011,4). The distinctive feature of signatures is that they "move and displace concepts and signs from one field to another (in this case, from sacred 
to profane, and vice versa) without redefining them semantically" (Agamben 2011, 4). Following this perspective, secularism is not a static state of affairs caused by a shift from a theological to a secular episteme and where the presence of religion should be considered a sign of secularism's crisis. Rather, secularism is an epistemic framework whose semantic register prompts a constant process of blurring, displacement, and renegotiation between secular and religious declensions.

In this article, building on the idea of "blurred boundaries" between the secular and the religious (Hurd 2017; see also Casanova 2006; Lynch 2010; Göle 2010; Scherer 2013) and following Agamben's idea of "secularization as signature," I contend that the power of neoliberalism stems from being a secular rationality of government that continuously evokes religious meanings and significations. Neoliberalism displaces and redraws the boundary between sacred and profane, and appropriates an aura of sacredness while concealing itself behind an authoritative secular rational façade. Hence, interrogating the idea of "neoliberalism as religion" means investigating how and to what effect seemingly secular/profane formations like the neoliberal market bear, display, and strategically mobilize the "signatures" of a religious/sacred episteme.

This analysis aims to contribute to three main fields of research. The first one is the growing body of scholarship that, over the last two decades, has questioned the accuracy, relevance, and explanatory power of the secularization theory. My goal is not to offer a competing theoretical perspective which may account for the presence of religion in modern societies, such as the "return of religion" approach (Petito and Hatzopoulos 2003; Thomas 2005; Snyder 2011; Sandal and James 2011) or the "secularreligious competition perspective" (Fox 2015). Rather, I want to interrogate the very meanings, boundaries and manifestations of the secular and the religious in modern societies beyond conventional understandings of what is generally understood as secular and as religious.

Second, and accordingly, this article aims to contribute to existing debates on neoliberalism and its epistemological foundations (Hayek 1989; Walker and Cooper 2011; Davies and McGoey 2012; Mirowski 2013; Chandler 2014), with a particular focus on questions of knowledge, ignorance, and belief in relation to the recent and still largely understudied phenomenon of "post-truth politics." I will show how post-truth politics can be conceptualized as a "leap of faith" in the neoliberal "truth market" of news production, circulation, and consumption where what counts as "true" is a function of the extent to which a "truth" is marketable, transferable, usable, and consumable. A "truthcommodity" counts as "true" insofar as it is capable to satisfying a need, particularly that of reaffirming and validating already existing understandings and biases in a marketplace that has multiplied and equalized all sources of knowledge irrespective of their authority. The sacralization of the neoliberal 
market of truth, I contend, has encouraged an "epistemology of limited knowledge" (Cooper 2011, 375), which governs through logics of commodification and belief.

Finally, albeit slightly more tangentially, this article aims to contribute to the expanding research on the power and the resilience of neoliberalism. This scholarship has advanced a series of elaborate economic, social, and cultural explanations to account for neoliberalism's remarkable strength despite its failures. These include: Marxist theories of "appropriation" (political institutions have become a tool of the economic and financial elites; Harvey 2010; Crouch 2011); ontological investigations into neoliberalism's amorphous, adaptable, and parasitical nature (Peck, Theodore, and Brenner 2010; Schmidt and Thatcher, 2013), which would make it a protean force capable of attaching itself to different social formations; critical approaches to resilience, which conceptualize "crisis" as an entrenched feature of neoliberal governmentalities (Walker and Cooper 2011; Joseph 2013, Evans and Reid 2014); and biopolitical/governmentality approaches that emphasize neoliberalism's capacity to channel crises into racism (Mavelli 2017) or scapegoating (Guénin-Paracini, Gendron, and Morales 2014). These accounts, however, have largely neglected the role that religious semantics and ideas may play in neoliberalism's astounding resilience.

The discussion unfolds in four main sections. In the first section, I discuss the idea of the secularization of the market through Weber's perspective and two modern iterations of his argument: philosopher Jürgen Habermas's and historian Bethany Moreton's. I consider how these approaches, despite their differences, understand the neoliberal market as fundamentally secular and disregard the possibility that it may have been progressively sacralized. In the second and third section, I first analyse Agamben's understanding of secularization and his notion of commodification as sacralization, and then focus on neoliberal forefather Friedrich Hayek's idea of the transcendent unknowability of the market. This analysis shows how the concept of "neoliberal sacralization of the market" is not just a facile and loose depiction, but an important analytical category that reveals significant transformations in neoliberalism. In the fourth section, I explore how post-truth politics is the expression of a neoliberal order increasingly governed by logics of commodification and belief in the benevolent inscrutability of the market. The conclusion spells out some of the implications of my argument for future research on secularism, neoliberalism, and post-truth politics, and for conceptualizing resistance to these interconnected regimes of power and knowledge. 


\section{The secularization of the market}

According to Stiglitz, the 2008 financial crisis should be understood as a product of twenty-five years of "market fundamentalism," which he describes as "the prevailing religion of the West." Over this time, he contends, the Western approach to the market

was not based on economic science or historical evidence. It was sold by Thatcher in the UK and by Reagan in the USA. It made reference to some old ideas in economics, specifically to Adam Smith's notion of the invisible hand, which is the argument that firms who pursue their self-interest and the maximization of profits would lead, as if by an invisible hand, to general societal well-being (Stiglitz 2009, 345).

Similar arguments have been increasingly made by numerous scholars and observers, including Fred Block and Margaret Somers, who argue:

Some use the term "neoliberalism," others "laissez-faire," and still others just plain "free market ideology." ... [W]e use the label "market fundamentalism" because the term conveys the quasi-religious certainty expressed by contemporary advocates of market self-regulation. Moreover, we want to emphasize the affinity with religious fundamentalisms that rely on revelation or a claim to truth independent of the kind of empirical verification that is expected in the social sciences (Block and Somers 2014, 3).

These remarks highlight an "elective affinity" between belief in an institutionalised religion and belief in the neoliberal market, and question the very secular nature of the latter. Following Freud, it could be argued that this affinity is the product of "an epistemological approach that privileges myth and the unquestioned authority of doctrinal tradition over evidence acquired through independent rational inquiry" (Hewitt 2014, 7). Yet, neither Stiglitz and Block and Somers, nor the others who have increasingly hinted at the religious nature of neoliberalism have attempted to explain the causes of the ascendancy of this epistemological approach. Two main questions follow: Is it meaningful and analytically useful to conceptualize neoliberalism as a form of religion? And, if so, how is it possible to account for the neoliberal "sacralization of the market"? Following Agamben, I address these questions through two contending understandings of secularization. First, in the remainder of this section, I discuss Weber's account and Habermas's and Moreton's modern renderings of his theory. Second, in the next two sections, I focus on Agamben's theory of secularization as "signature" and use this perspective to analyse the neoliberal sacralization of the market via a "religious" reading of leading neoliberal thinker Friedrich Hayek.

According to Weber, religion is not a timeless dimension of the human condition, but the first systematic attempt to address "the experience of the irrationality of the world" (Weber 1991 [1919], 123). "Irrational" for Weber (1991 [1919], 122) is a "world of undeserved suffering, unpunished injustice and hopeless stupidity." By acting as a rationalizing framework of meaning, religion performed three main purposes: serving as an epistemological framework that could account for the 
unknowns that surround life; explaining the "unjust suffering" and "unequal distribution of individual happiness" (Weber, 1991 [1915], 353); and act as a system of intersubjective moral norms. For Weber, all religions, despite their differences, share at their inception a distinctively rational goal: the attempt to rationalize the irrational that characterizes the human condition. Ironically, however, "the general result of the modern form of thoroughly rationalizing the conception of the world and of the way of life ... has been that religion has been shifted into the realm of the irrational" (Weber 1991 [1915], 281). As a result, science and bureaucratic rationality have progressively replaced religion as the hegemonic rationalizing framework of the modern order.

For Weber, this process can be vividly observed in the emergence of modern capitalism. In The Protestant Ethic and the Spirit of Capitalism (2003 [1905]), he famously argues that the main driver behind the development of capitalism is ascetic Protestantism. In particular, he maintains that the Calvinist notion of predestination - the idea that economic and social success may be taken as an indication of future salvation decreed by God - acted as a transcendent and disciplinary force that encouraged a virtuous and sober behaviour compliant with religious precepts. The ascetic Protestant way of life thus has its origins in a religious calling. Yet, the advancement of scientific rationalism engendered a process of secularization (which Weber refers to as "disenchantment") that resulted in a progressive separation of the spheres of religion and morality from that of the economy. Accordingly, the original rationale for the process of capitalist accumulation - the Calvinist religious calling - was progressively replaced by the "iron cage" of capitalism, namely, "the technical and economic conditions of machine production" and "care for external goods" - that is, mass consumption - "which today determine the lives of all the individuals who are born into this mechanism ... with irresistible force" (Weber 2003 [1905], 181).

It follows that capitalism for Weber is a secularized version of the protestant ethics. It is a regime of norms, practices and aspirations devoid of religious - i.e., moral - meanings and governed by a bureaucratic rationality that is ultimately an "iron cage" that locks modern individuals into a "meaningless" pattern of accumulation and consumption. Hence, from Weber's perspective, the idea that neoliberal capitalism may be considered akin to a religion is simply misplaced as capitalism is the ultimate embodiment of secularism and modern markets are the ultimate secular institutions. This view is powerfully articulated by Habermas in his recent critique of secularism.

For the German philosopher $(2008,111)$, secularization is the expression of a process of instrumental rationalization that has enslaved individuals in the impersonal and dehumanizing forces of "markets and administrative power." For this reason, he $(2008,107)$ argues, recovering the moral intuitions of faith becomes essential to counter a secular modernization that has replaced "domains of life that used to be held together by norms" with market "mechanisms of instrumental action guided by 
individual preferences" and the "uncontrolled dynamics of the global economy." Habermas thus advocates a postsecular shift, namely, a new role for religion in the public sphere as a source of inspiration for moral action. As he explains, religion has a "semantic potential" that "can "help us express our best moral intuitions without burning the bridges to secular languages and cultures'. We should respect the 'power of articulation' of religious language and recover the 'regenerative power' it offers for a 'dwindling normative consciousness'" (Habermas cited in Harrington 2007: 544).

Habermas's account can be read as a continuation of Weber's thesis and indeed as an attempt to reverse its tragic outcome. For Weber, one of the consequences of the "irrationalization" of religion has been the rise of the "iron cage" of secular bureaucratic rationality as embodied by the capitalist market system. For Habermas, in order to oppose this degeneration, the solution is to recover from religious traditions some universally valid moral principles which may contribute to re-moralize the market while continuing to preserve a formal separation between the secular and the religious spheres. Following Habermas, then, the idea that neoliberalism may be considered a form of religion is at best impressionistic - and therefore lacking any analytical value - and at worst deceptive, because the neoliberal market is the ultimate embodiment of the secular order. Accordingly, the growing unconditional acceptance of market logics - the rise of neoliberal "market fundamentalism" - would not be a religious phenomenon, but a manifestation of the anomic and de-humanizing secular rationality already identified by Weber over a hundred years ago.

A different reading of Weber's argument is offered by Moreton (2009), who focuses on the case of the United States. In her celebrated To Serve God and Wal-Mart, she argues against those dominant interpretations of Weber's thesis that see in the exponential acceleration of $20^{\text {th }}$ century mass consumption the ultimate manifestation of the secularization of the protestant ethics. To argue that "American Protestantism lost the battle" and that "[s]alvation gave way to self-realization," she argues, would be to miss the growing relevance of "the new Christian right of the 1970s and 1980s" and how it contributed to shape a "powerful counterculture" that "combined religious efforts to regulate sex," family values, communal life, ideas of citizenship, and understandings of the role of government "with an equally religious celebration of material comforts, self-expression, technological innovation, and secular success" (Moreton 2009, 87-88, 156).

For Moreton (2009, 86-88), what the new Christian right managed to accomplish was nothing less than "[s]anctifying capitalism and consumption under Christianity" with the effect that, in a reversal of the trajectory described by Weber, "[s]elf-realization placed salvation back into the centre of American public [and economic] life." In her account, this dynamic is vividly illustrated by the retailer giant WalMart. "People within the orbit of Wal-Mart," she explains, "learned to revalue shopping as selfless 
service to family, and service in turn as a sacred calling. In this context, the salient identity became not citizen-consumer nor worker of the world, but Christian servant" (Moreton 2009, 101).

At first sight, Moreton's argument may appear significantly different from Habermas's as she considers that the process of secularization described by Weber, at least as far as the United States is concerned, has not taken place or has been reversed. She suggests that the modern neoliberal order continues to be sustained (at least in the US) by the Protestant ethics and occasionally refers to the idea that the Protestant ethics has promoted "free-market economics as a sacred political cause" with the effect that "faith in God and faith in the market grew in tandem" (Moreton 2009, 167, 5).

However, at a closer look, Moreton's ontology of the neoliberal market is not radically dissimilar from Habermas's and Weber's. Indeed, for Moreton there is nothing inherently sacred about the neoliberal market. She regards it as a secular institution governed by principles of profit, risk taking, and entrepreneurship, whose ultimate rationale is generating material welfare and rewards, and most of all the possibility to "consume" and "helping others consume," which the Protestant ethic has reframed as "a sacred calling" (Moreton 2009, 107, 101) Unlike Habermas, she frames the market as a means to salvation rather than an expression of anomic and de-humanizing secular rationalities precisely because what she regards as sacred in the neoliberal order is not the market per se, but the possibility of "mass consumption" enabled by the market, which in the Protestant framework is a measure of spiritual grace and a testimony of a life lived by God's rule.

The analysis carried out in this section suggests that Weber's understandings of secularization, both in its original formulation and in the modern iterations of Habermas and Moreton, ultimately relies on a secular understanding of the market. From this perspective, the idea that the neoliberal market may have been sacralized appears impressionistic and analytically implausible. In the next two sections I explore a different perspective, first by discussing Agamben's contending understanding of secularization and his idea of commodification as sacralization, and then by considering Hayek's idea of the transcendent unknowability of the market. This analysis will suggest that the neoliberal sacralization of the market may not just be a facile description, but an analytical category that can enable us to grasp some important transformations in neoliberalism.

\section{The sacralization of the market (I): Commodification as sacralization}

To understand Agamben's theory of secularization, it is useful to start with an unfinished and fragmentary note written by Walter Benjamin in 1921 entitled "Capitalism as Religion." Contra Weber's theory of secularization, Benjamin (2004 [1921], 259) argues that capitalism is not "a 
religiously conditioned construction," but "an essentially religious phenomenon" that ultimately reproduces the same semantic register of established religious traditions. For Benjamin, secularization - "the suppression of religion by Enlightenment reason" - did not result in the overcoming of religion, but "left a blank space to be filled" which was occupied by capitalism as a new form of religiosity (Racy 2016, 89).

Taking cue from Benjamin's fragment, Agamben (2007) argues that capitalism pushes "to the extreme a tendency already present in Christianity," namely, "it generalizes in every domain the structure of separation that defines religion" (Agamben 2007, 81). In the case of religion, the separation in question is that between "sacred" (religious) and "profane" (secular). Capitalism, however, performs a different ontological separation, between things-in-themselves and things as commodities. Capitalism engenders an unbridled process of commodification which invests all spheres of human activity - literally "everything that is done, produced, or experienced," including "the human body," "sexuality" and "even language" - to the effect that it completely subdues and collapses the religious separation between sacred and profane (Agamben 2007, 81). As Agamben explains, the paradoxical result is "an absolute profanation without remainder [which] now coincides with an equally vacuous and total consecration" (Agamben 2007, 81). This means that, with the "absolutization" of the process of commodification, capitalism becomes a universal "sacred" framework and the market is turned into a quasi-religious entity.

This argument has two important implications. First, it does not suggest that there is "an identity of substance between theology and modernity, or a perfect identity of meaning between theological and political [or economic] concepts" (Agamben 2011, 4). Rather, what Agamben $(2011,4)$ emphasizes is that there is a "particular strategic relation that marks political [and economic] concepts and refers them back to their theological origin." His approach thus extends Carl Schmitt's famous theologicalpolitical paradigm - "All significant concepts of the modern theory of the state are secularized theological concepts" - to the economic domain (Agamben 2011, 2). For Agamben $(2009,40)$, the idea of secularization as signature "does not merely express a semiotic relation between a signans [theological concepts] and a signatum [the secular market]; rather, it is what - insisting on this relation without coinciding with it - displaces and moves it into another domain, thus positioning it in a new network of pragmatic and hermeneutic relations" in which "signum and signatum exchange roles and seem to enter into a zone of undecidability."

A second important implication of Agamben's theory of signature - though one not considered by Agamben - is that it enables a clarification of the connection between neoliberalism, capitalism, and theology as a concatenation of signa and signata. If capitalism bears the signature of theology, I wish 
to suggest, so does neoliberalism bear the signature of capitalism by radicalizing some of its features. In particular, from a Foucauldian perspective, neoliberalism can be understood as a process of "economization" whereby the traditional separation between politics, economy and society that characterized liberal forms of capitalism à la Adam Smith has been eroded (Foucault 2010, 242, 273276). The discrete logic of the liberal market has been progressively replaced by the totalizing logic of the neoliberal market which has become the overarching framework that through rationalities of competition, commodification, and inequality governs all spheres of human activity - from education, to work, leisure, and health, up to the whole social and political domain (Foucault 2010, 242; Dardot and Laval 2013, 17; Brown 2015, 31, Mavelli 2018). This process of neoliberal economization has increasingly erased the separation between "sacred" and "profane" - as the profane neoliberal logics of competition, commodification, and inequality invest every domain of life, including society, family, and the subjective sphere of the individual - thus performing a simultaneous re-sacralization of neoliberal market rationalities.

This argument, to be sure, acknowledges that neoliberalism "is neither singular nor constant in its discursive formulations, policy entailments and material practices" (Brown 2016, 4) and that therefore it exists in different forms and socio-political contexts. In this article, however, my concern is not with the varieties of neoliberalism, but with the identification of some general features that make the neoliberal sacralization of the market a globally relevant process and, to borrow Weber's (2003 [1905], 17) famous sentence, one of the "most fateful force[s] in our modern life" - one that blurs and rewrites the very separations between secular and religious, sacred and profane.

From this perspective, the neoliberal market system may not be a purely secular domain as Weber and Habermas maintain, but a "zone of undecidability" that constantly refers back to religious meanings and significations and that displaces, blurs, and reframes the boundary between sacred and profane. Agamben's approach also points to a different understanding of neoliberalism and secularization than that advanced by Moreton. Although Moreton's argument may give the impression that the sacred act of serving God and the profane act of serving Wal-Mart exist in a zone of undecidability, this is not really the case. As previously discussed, in her account, the neoliberal market is not inherently sacred. It is a secular institution whose rationale is to generate material welfare through mass consumption: a purely secular endeavour that, in the Protestant narrative, is also necessary to connect with God and live by God's commandments. For Moreton, the market may be considered to be sacred only insofar as it is capable to generate material welfare, rewards, and success. The sacralization of neoliberal market rationalities foregrounded by Agamben, on the other hand, appears independent from the capacity of the market to advance economic growth. 
To appreciate the significance of this argument, it is useful to briefly consider Pope Francis' (2013) recent critique of the existing economic order as articulated in his first Apostolic Exhortation, Evangelii Gaudium (The Joy of the Gospel). This document offers a remarkable illustration of Agamben's argument. For Francis, there is a fundamental tension between the "outcomes" of the current economic system and the "faith" that supports its existence. The present "economy of exclusion and inequality" kills as it rests on Darwinian logics that foster exploitation and indifference to human suffering. Nowadays, he $(2013,45)$ argues, "everything comes under the laws of competition and the survival of the fittest" with the effect that "masses of people find themselves excluded and marginalized, without work, without possibilities, without any means of escape." Hence, how is it possible that despite these tragic outcomes people continue to believe in "trickle-down theories" and their capacity to bring "greater justice and inclusiveness in the world"? (Pope Francis, 2013, 48) The problem, the Pope argues, is that "the prevailing economic system" has been "sacralized;" the "deified market" has "become the only rule" (Pope Francis, 2013, 48). This has been made possible by the reduction of "man" [sic] "to one of his needs alone, consumption." The "unbridled consumerism" of "today's economic mechanism" has contributed to turning "human beings" into "consumer goods" (Pope Francis, 2013, 46-50), that is, into commodities.

Similarly to Agamben, Francis suggests that the split between life itself and life as commodity erases the boundary between the sacred and the profane. Life is no longer sacred as it is commodified, exchanged, and consumed in the name of a market logic that has donned an aura of sacredness that invests all domains of existence. The absolute commodification of everything - including life performed by capitalism has ultimately contributed to sacralise the neoliberal market. In the next section, I explore the other crucial condition of possibility of the sacralization of the market: a belief in its transcendent unknowability that ultimately demands, to borrow Francis's words, an unconditional belief in its "sacralised workings." To explore this issue, the focus now turns to leading neoliberal thinker Friedrich Hayek.

\section{The sacralization of the market (II): The transcendent unknowability of the market}

Hayek is often regarded as "the single most important neoliberal economist" (Gaffney 2017, 124). Nobel Prize winner in 1974, Hayek's "subjectivist" strand of neoliberalism has received increasing attention in recent scholarship and policy discussions. His views have inspired existing debates on the shift from neoclassical equilibrium theory to processes of permanent adaptation, and on risk 
governance and the impossibility for states to place themselves "outside the logic of risk and speculation" through centralized knowledge (Konings 2016, 278). Over the last two decades and particularly in the aftermath of the 2008 financial crisis, Hayek's views have progressively turned from "minor tradition" to major analytical perspective (Cooper 2011; see also Walker and Cooper 2011; Konings 2014) to the point of challenging the hegemony of the "positivist" Chicago School of Economics, which for many scholars and observers had long represented the ultimate embodiment of neoliberalism (see, for instance, Klein 2007).

The "subjectivist" and "positivist" strands of neoliberalism share the idea that market-based competition rewards ingenuity and innovation, maximizes individual and aggregate utility, and enables the efficient circulation and allocation of capital. However, they differ on the limits and possibilities of market intervention. Whereas the Chicago School considers that a certain level of political intervention may be necessary to preserve the correct and smooth functioning of the market, for Hayek (2005 [1944], 210; see also 1945, 1952, 1967, 1989) the idea that human beings may govern the market in order to improve its functioning is the expression of an "erroneous rationalism," namely, the mistaken presumption that human minds may have greater computational capacity than the market. For Hayek, markets are "complex systems" comprising of an extraordinary high number of variables that greatly exceed the human capacity to grasp them in their totality. At the same time, markets also have an innate and spontaneous capacity to produce order, progress, and growth (Hayek 1967; see also Walker and Cooper 2011). Hence, any human attempt to intervene on the market will negatively affect its performance and, as I shall discuss in a moment, potentially threaten our freedom by establishing new forms of tyranny.

Tyranny is for Hayek a direct consequence of the hubris of scientific knowledge. By claiming an unprecedented ability to grasp and successfully intervene upon the complexity of the market, scientific rationalism endows "other men" in the guise of communist dictators, socialist planners, leftist redistributionists, and central bankers with the "arbitrary power" to compress our freedom (Hayek 2005 [1944], 204-5). It follows that the only way to escape the "serfdom of the individual" and defend our liberty "rests chiefly on the recognition of the inevitable ignorance of all of us" (Hayek 2011 [1960], 80), namely, on the recognition that individuals only possess scattered fragments of knowledge and that government cannot overcome the inherent unknowability of the market. For Hayek, relinquishing the myth of scientific knowledge is not a cause for despair because " $t \mathrm{t}]$ here is not much reason to believe that, if at any one time the best knowledge which some possess were made available to all, the result would be a much better society. Knowledge and ignorance are relative concepts." (Hayek cited in Mirowski 2013, 66; emphasis mine) 
Hence, to preserve our freedom, we need to embrace the idea that the market is fundamentally unknowable in its totality and that the market has an endogenous agency that transcends our individual and collective agency, which is precisely what makes knowledge and ignorance relative. To preserve our freedom, Hayek intimates, it is paramount to believe in the truth of the market in very much the same way that "men in the past" used to believe in the truth of religious traditions. As Hayek (2005 [1944], 210) explains,

It was men's [sic] submission to the impersonal forces of the market that in the past has made possible the growth of civilization ... It does not matter whether men in the past did submit from beliefs which some now regard as superstition ... The refusal to yield to forces which we neither understand nor can recognize as the conscious decisions of an intelligent being is the product of an incomplete and therefore erroneous rationalism. It is incomplete because it fails to comprehend that co-ordination of the multifarious individual efforts in a complex society must take account of facts no individual can completely survey.

Hayek $(1989,137)$ admits that this faith in the market is ultimately not "verifiable or testable". Yet, he maintains, the very advancement of progress and civilization is also the product of "beliefs which are not true ... in the same sense as are scientific statements and which are certainly not the result of rational argumentation" (Hayek 1989, 137). These beliefs or "symbolic truths," as Hayek $(1989,137)$ describes them by citing The Book of Genesis, have forcefully encouraged "their adherents to "be fruitful and multiply and replenish the earth and subdue it' (Genesis 1, 28)." Indeed, he concludes, "nonfactual beliefs" have been essential for the establishment of "the extended order that we now enjoy" to the effect that "now the loss of these beliefs, whether true or false, creates great difficulties" (Hayek 1989, 137).

It can be inferred that for Hayek the Weberian process of disenchantment - the shift from religious rationalism to scientific rationalism and the related downgrading of "belief" to the sphere of the irrational - threatens the advancement of human civilization. Weber's (1991 [1919], 293) famous idea that, with modernity, "there are no mysterious incalculable forces that come into play, but rather that one can, in principle, master all things by calculation" becomes for Hayek the very condition of possibility of the "erroneous rationalism" (Hayek 2005 [1944], 210) and "pretence of knowledge" (Hayek, 1989) that pose a grave threat to human freedom. Hence, to be free and to advance our material and civilizational well-being, we have no choice but to bow to the inscrutable mysteries of the market by abandoning our "pretence of knowledge" (Hayek 1989), confessing our ignorance, and letting ourselves be guided by the wisdom of a superior intellect - the neoliberal market - whose impenetrable design we can neither understand nor grasp in its totality. 
Hayek's idea of the neoliberal market offers a remarkable instantiation of secularization as signature. His approach mixes secular and religious registers. It blurs the divides between science and faith, facts and beliefs, the secular and the religious as well as the practical and moral divide between knowledge and ignorance. In an almost mystical and transcendent turn, it gestures towards the unknowability and inscrutability of the market, thus asking for an act of faith in its inherent goodness. Yet, this act of faith is justified in purely secular-rational terms concerning the epistemological limits of scientific knowledge. The result is a process of dislocation of religious signa and secular signata that constantly blurs the boundary between sacred and profane, thus producing what Agamben would describe as "a zone of undecidability." The neoliberal market is sacralized, and yet its sacralization does not seemingly rest on revelation, but on a secular rationality that reveals the inherent epistemological limits of our capacity to know due to the sheer complexity of the market. And yet again, at a closer look, Hayek's secular scientific reasoning also crucially encompasses an element of revelation concerning the natural goodness of the market. As Miguez, Rieger and Sung $(2009,82)$ perceptively observe,

[I]f it is true that we cannot sufficiently understand the factors and dynamics of the market so that we can intervene in it, how can we know that the market always produces beneficial effects or that it is essentially a "force for good"? Is knowing that the market always produces beneficial effects not a pretension of knowledge of the market? Since one cannot prove this providential character of the market, we have here a "leap of faith" in the affirmation of the essentially beneficent quality of free market.

This, however, does not mean that Hayek's neoliberalism resembles a religion. The ultimate justification for trusting the market is the expression of an eminently scientific and secular rational argument: our epistemological incapacity to fully grasp the complexity of the social world in its sheer intricacy. However, through a "leap of faith," this secular approach ends up advocating trusting the market as a benevolent entity capable of delivering economic growth and advancing the pathway of human civilization. This reasoning performs a paradoxical subversion whereby it is rational to have faith in the market - even when the market delivers crisis, shocks, and failures - and it is irrational not to have faith in the market - as this would express a "pretence of knowledge" that clashes with secular registers. In Hayek's account, secular and religious registers are inextricably mixed and "signum and signatum exchange roles and seem to enter into a zone of undecidability." (Agamben 2009, 17) The neoliberal market thus emerges simultaneously as a sacred and profane space that draws strength on competing frames of authority, and results in a power that transcends both secular and religious registers. 
The analysis carried out in this and in the previous section suggests an important provisional conclusion. The sacralization of the market is the product of: a) an unbridled commodification that undermines the sacred/profane separation; and, b) a fundamental condition of unknowability and ignorance that invites us to submit ourselves to the impersonal forces of the market in order to eschew "the arbitrary power of other men" (Hayek 2005 [1944], 205). In the next section, I investigate the relevance of this argument in relation to the phenomenon of post-truth politics, which I approach as the instantiation of a sacralized neoliberal "truth market". As mentioned in the introduction, this case is particularly relevant because it enables us to investigate the meanings, boundaries, and manifestations of the secular and the religious beyond their conventional understanding, and because it shows how neoliberal rationalities of government crucially encompass logics of belief.

\section{Neoliberalism, belief, and post-truth politics}

In 2016, the Oxford English Dictionary declared "post-truth" its "Word of the Year." This term relates to or denotes "circumstances in which objective facts are less influential in shaping public opinion than appeals to emotion and personal belief." ${ }^{1}$ The choice came at the end of a year dense of political events - most notably, the so-called Brexit referendum in the United Kingdom (UK) concerning the exit of the country from the European Union (EU) and the election of Donald Trump in the United States - which had been dominated by the widespread and successful use of false claims to achieve political goals. What many observers consider to be new of this phenomenon is not the use of false claims per se in the political debate, but the fact that these claims continue to retain their political force despite being extensively debunked by multiple and authoritative sources.

Consider one of the most powerful slogans of the "Leave" campaign in the Brexit referendum: the promise to reroute the alleged $£ 350$ million a week that the UK sends to the EU to the National Health Service (NHS). The claim that EU membership cost $£ 350$ million a week to the UK was challenged by numerous authoritative bodies, including the UK Statistics Authority and the Institute for Fiscal studies, on the grounds that it did not take into account the rebate and the money paid back to the UK through "Commons Agricultural Policy, regional development funding, scientific grants, or cultural grants" (Stone 2016). Nonetheless, this slogan continued to make headlines, circulate on social media, and capture public imagination and attention, with the effect of becoming one of the most powerful tools in the hands of the "Brexiteers."

\footnotetext{
${ }^{1}$ https://en.oxforddictionaries.com/word-of-the-year/word-of-the-year-2016, accessed 12 September 2018.
} 
The day after the referendum, Nigel Farage, then leader of the UK Independence Party (UKIP) and one of main forces behind the referendum, had to admit that after the exit of the UK from the EU, $£ 350$ million a week may not be available for NHS. More explicitly, businessman Arron Banks, the main funder of UKIP and Leave.EU campaign, stated that they knew from the start that "[f]acts don't work ... The remain campaign featured fact, fact, fact, fact, fact. It just doesn't work. You have got to connect with people emotionally. It's the Trump success" (Worley 2016). Does this case of blatant trashing of facts, and the many others that have punctuated the political debate over the last few years, suggest that we have entered a phase of "post-truth politics"? To answer this question, it is useful to reflect on Michel Foucault's understanding of truth. For Foucault,

[e]ach society has its regime of truth, its "general politics" of truth: that is, the types of discourse which it accepts and makes function as true; the mechanisms and instances which enable one to distinguish true and false statements, the means by which each is sanctioned; the techniques and procedures accorded value in the acquisition of truth; the status of those who are charged with saying what counts as true (Foucault 1980, 131).

Yet, Foucault warns, truth has nothing to do with veracity, sincerity, accuracy, validity, factuality or authenticity. Truth is "a system of ordered procedures for the production, regulation, distribution, circulation and operation of statements" (Foucault 1980, 133). A regime of truth is thus the product of a system of power that it contributes to sustain by promoting a series of rules "according to which the true and the false are separated and specific effects of power attached to the true" (Foucault 1980, 132). From this perspective, the question to ask is not whether we have entered a post-truth phase which is clearly not the case as this would mean transcending power, hence achieving what Foucault would consider an ontological impossibility. Rather, the question is whether the system of power and rules "according to which the true and the false are separated" has changed from a situation in which it was mainly "produced and transmitted under the control, dominant if not exclusive, of a few great political and economic apparatuses (university, army, writing, media)" (Foucault 1980, 131), to one characterized by a "new temporality and spatiality of news production, circulation, and consumption" in which "power exploits [our] new "freedoms" to participate/produce/express (as well as consume/diffuse/evaluate)." (Harsin 2015, 327)

In the previous sections, I discussed how neoliberal commodification entails a simultaneous process of profanation - things are separated from themselves and turned into commodities - and sacralization - the commodification of everything turns the market into a universal "sacred" system of meanings and significations. This process, I want to argue, has had two main implications for the current "regime of truth:" it has increasingly turned facts into commodities and it has favoured the proliferation of a neoliberal "truth market" (Harsin 2015) with the effect of further eroding the never settled boundary between "facts" and "beliefs." Let me analyse these two dynamics in turn. 
In order to understand the current "commodification of facts," it is necessary to consider how the socalled digital revolution has resulted in the exponential proliferation of new information channels online newspapers and radios, podcasts and, most of all, social media such as online communities, blogs and feeds - which have contributed to increase the offer of news in a regime of increased competition and personalization. These developments have often been praised on the grounds that competition improves the quality of the product - the truthfulness, reliability and depth of the news - and enables democratic participation by multiplying the sources of information, which are no longer monopoly of established media and broadcast corporations. Moreover, the "algorithmic selection of news by social media platforms" (Rulyova and Westley 2017, 995) seemingly enables us to more closely follow the issues, questions, and debates we are interested in and thus increases our knowledge and critical awareness.

However, the transformation of news, facts, and opinions into commodities has also contributed to changing their meaning and goal: from informing, encouraging critical thinking, and instilling doubt to satisfying a need, namely, the validation of pre-existing cognitive biases. The algorithmic personalization of information means that we are more likely to receive in our social media feeds stories, news, and perspectives that confirm our established beliefs. This algorithmic segmentation has fed an exponential demand for "echo chambers, filter bubbles, and confirmation bias" (Glaser 2016). This demand has increasingly been met by a growing offer of "fake" or "junk-food news" (Viner 2016) both by established and less established news sources all engaged in a competitive struggle to attract "clicks" and "traffic," and therefore advertising, money, and investments. In this environment, it does not matter whether a story is real; what matters is only "whether people click on it" (Glaser 2016).

The neoliberal commodification of facts has increasingly worn down the already labile and often arbitrary separation between "facts" and "beliefs." It has contributed to desacralize or profanate the authority of established media (which have often desacralized and profanated themselves by accepting the logics of neoliberal commodification) by creating a false equalization that does not value authority, complexity, rigour, and depth, and assesses the "truthfulness" of a story in terms of "sales," namely, "clicks," "likes," or number of times it is shared. This, in turn, has contributed to enthroning the neoliberal logic of the market as the "sacred" framework that should govern the production, circulation, distribution and recognition of facts. A most visible manifestation of this dynamic has been the emergence of a "truth market" (Harsin 2015) in which a plethora of rival "marketplaces" newspapers, communities, blogs, radios - compete against each other in order to secure the trust and allegiance of their "customers" (readers, viewers or listeners) by offering them the stories they want 
to hear as well as "empowering" them, by giving them the "freedom" to voice their views, opinions and anger through their electronic platforms.

The fiduciary and pastoral role of these marketplaces has been heightened by the expansion and complexification of the existing neoliberal market of truth. This has prompted an "information overload" whereby "at the very moment when we have the technology available to inform ourselves as never before, we are simultaneously and compellingly confronted with the impossibility of ever being fully informed" (Andrejevic 2013, 2). As Mark Andrejevic (2013, 2) observes, this is particularly disturbing given that we are increasingly told that "being informed is more important than ever before to our livelihood, our security, and our social lives." In this environment, the marketplaces of truth become the media which enable us to trust the neoliberal market of truth: although we are overwhelmed by an overabundance of information that we are not able to examine, let alone fully decipher and grasp, we can nonetheless trust the superior capacity of truth marketplaces to select the relevant information for us and offer spiritual guidance. Truth marketplaces are thus the religious ministers that navigate us through the mysteries of the neoliberal market of truth.

This argument draws and elaborates on the Hayekian perspective discussed in the previous section. The direct relationship between the neoliberal citizen - the believer - and the neoliberal market - the transcendent God-like reality - discussed by Hayek is here mediated by the role of "truth marketplaces"/religious ministers that negotiate and facilitate this relationship. Nonetheless, the substance of Hayek's argument is unchallenged: belief in the market is justified by its superior processing might and our incapacity to grasp its complexity. From this perspective, the rise of posttruth politics is a form of unreserved belief in the secular and neoliberal market of truth that further erodes the already fragile boundary between facts and beliefs. In line with Hayek's argument this belief is not only justified by our ignorance, but by a quest for freedom that requires depriving the socalled experts - whether embodied by public officers, academics, specialist journals, authoritative newspapers, or other respected media - of their alleged "monopoly of truth."

Hence, it is not by accident that during the Brexit campaign, when challenged on the economic, social and political implications of Brexit, prominent Tory Brexiteer Michael Gove stated that "People in this country have had enough of experts" (cited in Glaser 2016), that is, they have had enough of their "truths." Similarly, during one of his electoral rallies, Donald Trump declared his "love" for "the poorly educated:" "We're the smartest people, we are the most loyal people," he said, including himself in the category (The Independent 2016). In both accounts, ignorance is not presented as a condition to be ashamed of or to be opposed. Quite the opposite, as Mirowski observes in his discussion of Hayek, ignorance is a status to be promoted because it encourages reliance on the superior wisdom of the 
neoliberal market - and of its ministers - and this is what makes it possible to escape the tyranny of the "regime of truth" of "other men" (Hayek, 2005 [1944]: 205).

In these accounts, consistent with Hayek's view, ignorance is not perceived as a form of irrational surrender to transcendent forces. Indeed, drawing on Hayek (2011 [1960], 378), it can be described as a secular and rational reappropriation of agency and an act of resistance against "the men who are most needed and most powerful in modern government, namely, the efficient expert administrators exclusively concerned with what they regard as the public good" who are the ones who "pose [t]he greatest danger to liberty today". This view, which for Hayek originated from an epistemological problem on the limits and conceits of modern scientific knowledge, has established itself as a powerful public discourse. Two main explanations can be advanced for this pattern. First, as Tom Nichols (2017, 63) observes, the "overwhelming complexity" of modern life has produced widespread "feelings of helplessness and anger among a citizenry that knew itself to be increasingly at the mercy of more sophisticated elites". Second, this sense of helplessness in the face of complexity has been perceived through an almost uninterrupted and overlapping series of crises - from terrorism, to climate change, to the global financial and migration crises - which have resulted in a politics of fear and securitization accompanied by regimes of economic austerity. The result has been growing marginalization, social and political disenfranchisement, and a widespread sense of uncertainty.

In conceptual terms, then, the revolt against the expert elites - a defining featured of post-truth populist politics - can be understood as one of the products of the betrayed promise of modernity, namely, "the promise that the unknown could be made known" and that "time and space truly could be brought under human control through Reason." (Jack Amariglio, cited in Burczak 1994, 33) For Nichols, this complexity-cum-crisis has produced what, following Jeffrey Stout (1981), could be described as a secular "flight from authority" whereby "the people", "[u]nable to comprehend all the complexity around them", have chosen "instead to comprehend almost none of it and then sullenly blame elites for seizing control of their lives;" that is, they have chosen to abandon themselves to the consolations of "fake news" and conspiracy theories that offer a simplified picture of the outside world and validate existing cognitive biases (Nichols 2017, 72, 66-69).

From a broader theoretical perspective, the betrayed promise of mastery and control of modernity has prompted a proliferation of social ontologies that strive to render meaningful and account for the complexity-cum-crisis of the modern condition (see Joseph 2013, 39). Ulrich Beck (2010), in particular, argues that this condition has prompted a modern revival of faith. According to the German sociologist, new religious belief are spreading "in proportion to the growth of insecurity triggered by radicalized modernization processes in every sphere of human social activity" (Beck 2010, 85). These new beliefs are not anti-modern, but thoroughly modern. They do not seek to revive the orthodox 
framework of institutionalized religions, but are the expression of "a new kind of subjective anarchy of belief" (Beck 2010, 85). This means that the individual, through the establishment of microcommunities of faith, "becomes increasingly adept in creating faith narratives for himself $-a$ 'God of his own" - adapted to his "own" life and his “experiential horizon"” (Beck 2010, 85-86).

These two dynamics - the revolt against the expert elites and the proliferation of "fake news" on the one hand, and the modern revival of faith with the spreading of new religious beliefs on the other are not independent phenomena. They are part of a process of disintermediation encouraged by a growing belief in the superior and inscrutable capacity of the market to act as a mechanism of social coordination. The process of fragmentation of belief described by Beck, therefore, transcends the limits of established monotheistic religions (Christianity, Islam and Judaism), which are the focus and scope of his analysis. It concerns the very secular sphere and the crisis of its authoritative hierarchies and frameworks of knowledge. The proliferation of "fake news" and conspiracy theories that provide a simplified account of the world through the validation of existing cognitive biases can thus be understood as process of desacralization of the "truth" of authoritative expert knowledge and of simultaneous sacralization of the neoliberal "truth market" and its religious ministers, the "truth marketplaces." From this perspective, the consumption and production of "fake news" can be conceptualized as a quest for "a God of one's own": as a quest for identity and communities of likeminded people and beliefs, which may provide understandable and reassuring frameworks of meaning against the complexity-cum-crisis of the modern condition.

The secular episteme - and, in this specific case, the sphere of news production, circulation, and consumption - thus increasingly mobilizes the "signatures" of religious frameworks of meanings and significations, with the effect of performing a relentless dislocation of the boundary between the secular and the religious. The "flight from the authority" of the expert elites is simultaneously a quest for freedom and autonomy, and for identity and community, which ultimately endows the market with the capacity to establish a meaningful order out of "the dispersed bits of incomplete and frequently contradictory knowledge which all the separate individuals possess" (Hayek 1945, 519). In this neoliberal political theology of the post-truth, however, the abdication to the transcendent might of the market is an illusory reappropriation of agency. The possibility of commenting, posting news items, retweeting, sharing, circulating rumours, spreading unsubstantiated facts, "liking" and "disliking" is increasingly transforming us into the sounding board of our respective marketplaces of truth. We are proselytizing agents only seemingly divided by different cults of truth.

Our quest for reassurance - concealed by a secular simulacrum of agency in our capacity to click, post, comment, share, and (re)tweet - betrays a willingness to believe in the "marvel" of a neoliberal truth market capable to "move in the right direction ... without more than perhaps a handful of people 
knowing the cause" (Hayek 1945, 527). In the neoliberal political theology of post-truth, the value of our ideas is no longer a function of their veracity, facticity, morality or critical insight, but of a market scheme of valuation that, through logics of competition and segmentation aimed at targeting difference audiences of consumers/producers of news, measures value in terms of rankings, market penetration, and volumes - of "traffic," "clicks", "likes", "comments", "followers", "tweets", "shares", "reviews", and so on. And, yet, as I have endevoured to show in this section, this segmentation is ultimately indistinguishable from a quest for community that, through the search for and consumption of a neoliberal commodified God to believe in - a "God of our own" - may endow us, at least temporarily, with sense of meaning, identity, and belonging.

\section{Conclusion}

According to Agamben $(2011,1)$, two paradigms have "exercised a decisive influence on the development and the global arrangement of Western society": political theology and economic theology. Whereas the former has been the object of extensive investigation through "[p]olitical philosophy and the modern theory of sovereignty," the latter has received substantially less attention (Agamben 2011, 1). The religious dimension of "the current triumph of economy and government over every other aspect of social life," Agamben $(2011,1)$ maintains, is still largely "in the shadows." In this article, I have attempted to shed some light on this largely neglected paradigm by interrogating the notion of "neoliberalism as religion." To this end, I first considered the limits of the Weberian understanding of secularization and two of its most important modern iterations - Habermas's and Moreton's - to account for the neoliberal "sacralization of the market". Then, through Agamben's "theory of signatures," I approached secularism as an epistemic framework that, by continuously evoking religious meanings and significations, prompts a constant process of blurring, displacement, and renegotiation of the "sacred" and the "profane." From this perspective, I investigated neoliberalism as a secular mode of government whose power and resilience rest on its capacity to appropriate religious rationalities, modes of revelation, and frameworks of transcendence.

In particular, focusing on Agamben's reflections on capitalism and Hayek's rendering of neoliberalism, I showed that the sacralization of the market is the joint outcome of an unbridled process of commodification that undermines the sacred/profane separation and of a fundamental condition of unknowability that requires that we submit to the transcendent mysteries of the market in order to enjoy freedom and wealth. As part of this analysis, I strived to offer a new reading of Hayek's neoliberalism by showing how it mixes secular and religious registers, blurs the divides between knowledge and ignorance, and eventually demands an act of faith in the market's ultimate goodness. 
For Hayek, the hubris of thinking that the market may be understood, managed, and acted upon will inevitably result in the "the nemesis of the planned society," namely, in the decline of reason as manifested in the compression of freedom and reduction to serfdom. ${ }^{2}$ I showed how Hayek's neoliberalism - which has acquired growing explanatory, normative, and practical relevance in the aftermath of the 2008 financial crisis - is, in Agamben's terms, "a zone of undecidability" that sacralizes the market through a profane secular reason. The latter encourages the acceptance of revelation - the inherent goodness of the market - as the only rational course of action.

This analysis suggests a contending path to explore the resilience of neoliberalism beyond existing economic, social, and cultural explanations. The power of neoliberalism rests on its capacity of being both sacred and profane by presenting itself through an authoritative secular rational façade, while drawing on a religious semantic register that evokes a mystique of inscrutability and transcendence. The power of neoliberalism rests on its capacity to be fully within and at the same time beyond the secular domain. From this perspective, our "secular age" is not one in which "non-belief" is "the default option," as philosopher Charles Taylor (2007) has famously argued. In fact, we do not even live in a secular age. We live in a process of permanent secularization that constantly renegotiates, displaces, and reappropriates religious meanings and significations through an endless dynamic of neoliberal profanation and sacralization of all spheres of human existence.

In the final section of the article, I investigated this dynamic with reference to the emergence of socalled post-truth politics. I explored how this phenomenon is an outcome of the neoliberal sacralization of the market of news consumption, circulation, and production. This analysis showed how neoliberal rationalities have penetrated and govern the domain of news, fake news, and false news, and how these rationalities do not simply encompass logics of competition and commodification, but also belief. In particular, I considered how the commodification of facts has eroded the already labile and arbitrary separation between "facts" and "beliefs" by desacralizing the "truth" of authoritative and expert knowledge and sacralising an ultimately unknowable "truth market." The latter's sheer complexity and ultimate unknowability requires that we place our unreserved faith in and swear our unconditional allegiance to some "truth marketplaces:" the religious ministers that can navigate us through the mysteries of the neoliberal market of truth and enable us to benefit from its inherent goodness, namely, its capacity to increase our freedom and escape the tyranny of the "regime of truth" of "experts."

\footnotetext{
${ }^{2}$ Nemesis was the Greek goddess of retribution that punished acts of hubris against the gods; "Hubris of Reason" and "The Nemesis of the Planned Society" were the title of the two main sections that Hayek originally envisaged for The Abuse and Decline of Knowledge (see Ebenstein 2014, 107).
} 
This analysis suggested that the phenomenon of post-truth politics should be understood as part of a broader process of disintermediation concerning the religious, social, and political sphere - as manifested, for instance, in global rise of populism - encouraged by a growing belief in the superior and inscrutable capacity of the market to act as a mechanism of social coordination capable of advancing individual and collective freedoms. Yet, this belief was shown to conceal a fundamental quest for "a God of one's own:" a quest for identity and communities of belief capable of providing meaningful, reassuring and comforting narratives against the complexity-cum-crisis of the modern condition. The consumption/production of news, fake news, and false news thus emerged as increasingly indistinguishable from an act of faith in the inscrutable mysteries of a neoliberal market fluctuating between secular and religious registers.

The analysis carried out in this article was implicitly inspired by the willingness to problematize Michel Foucault's $(1984,88)$ intuition that "knowledge is not made for understanding; it is made for cutting," and therefore, by the idea that power manifests itself as a regime of caesuras. My focus was on the need to move beyond the caesura between the secular and the religious and what is traditionally recognized as secular and religious and investigate how a whole new regime of neoliberal caesuras has supplanted and blurred the latter. In particular, neoliberalism has introduced two main caesuras: the one between things-in-themselves and things-as-commodities, and the one between ourselves and the unfathomable market. Both divides mutually reinforce each other and have contributed to sacralise and extend the grip of neoliberalism on all spheres of life. This analysis reveals how neoliberalism absorbs, rewrites, and profanates non-economic domains and thus brings to the fore some crucial interconnections between secularization, neoliberalization, and the emergence of new dynamics, such as post-truth politics.

One of the outcomes of the neoliberal sacralization of the market has been the further degradation of the boundary that separates facts from beliefs, knowledge from ignorance, freedom from subjugation, active participation from mere consumption. This neoliberal liquid space mixes secular and religious registers and calls for new forms of critical engagement that strive to grasp their disarticulation, rearticulation, and deployment in existing regimes of power. Such a perspective needs to move from the recognition that neoliberalism has no outside. Hence, to think critically about our current secular-religious predicaments, it is necessary to investigate not just the neoliberal "cutting" of power/knowledge regimes but also their "sewing" to shape domains, such as the market, and phenomena, such as post-truth politics, that simultaneously incorporate, combine, and transcend secular and religious registers. 
This means that investigating the relationship of the secular and the religious in modern societies requires de-essentializing these categories as well as acknowledging how their contingent and mutable qualities are also a function of neoliberal regimes of power and knowledge. It means that challenging the neoliberal order requires considering how traditionally understood secular domains such as the market employ religious semantics, styles, and tones that eventually undermine the very separation between "the secular" and "the religious." And it means that resisting post-truth politics requires interrogating how our very understanding of "facts" and "beliefs" has been reframed by the "sacralized" neoliberal logic of the market. 


\section{References}

Agamben, Giorgio. 2007. Profanations. New York: Zone Books.

Agamben, Giorgio. 2009. The Signature of All Things, On Method. New York: Zone Books.

Agamben, Giorgio. 2011. The Kingdom and the Glory: For a Theological Genealogy of Economy and Government. Stanford: Stanford University Press.

Andrejevic, Mark. 2013. Infoglut: How Too Much Information is Changing the Way We Think and Know. London: Routledge.

Benjamin, Walter. 2004 [1921]. “Capitalism as Religion.” In Selected writings 1: 1913-1926.

Cambridge, MA: Harvard University Press.

Beck, Ulrich. 2010. A God of One's Own: Religion's Capacity for Peace and Potential for Violence. Cambridge: Polity.

Block, Fred, and Margaret R. Somers. 2014. The Power of Market Fundamentalism: Karl Polanyi's Critique. Cambridge, MA: Harvard University Press.

Brown, Wendy. 2015. Undoing the Demos: Neoliberalism's Stealth Revolution. New York: Zone Books.

Burczak, Theodore A. 1994. "The postmodern moments of FA Hayek's economics." Economics \& Philosophy 10(1): 31-58.

Casanova, José. 1994. Public Religions in the Modern World. Chicago: University of Chicago Press.

Casanova, José. 2006. "Secularization Revisited: A Reply to Talal Asad," in Powers of the Secular Modern: Talal Asad and His Interlocutors, edited by David Scott and Charles Hirschkind. Stanford: Stanford University Press.

Chandler, David. 2014. Resilience: The Governance of Complexity. Abingdon and New York: Routledge.

Cooper, Melinda. 2011. "Complexity Theory After the Financial Crisis: The Death of Neoliberalism or the Triumph of Hayek?" Journal of Cultural Economy 4(4): 371-385.

Crouch, Colin. 2011. The Strange Non-Death of Neo-Liberalism. Cambridge: Polity. 
Dardot, Pierre, and Christian Laval. 2013. The New Way of the World: On Neoliberal Society. London: Verso.

Davies, William and Linsey McGoey. 2012. "Rationalities of Ignorance: On Financial Crisis and The Ambivalence of Neo-Liberal Epistemology. Economy and Society 41(1), 64-83.

Dean, Mitchell. 2014. Rethinking Neoliberalism. Journal of Sociology 50(2): 150-163.

Ebenstein, Alan. 2014. Friedrich Hayek: A Biography. London: St. Martin's Press.

Evans, Brad and Julian Reid. 2014. Resilient Life: The Art of Living Dangerously. Cambridge: Polity Press.

Foucault, Michel. 1980. Power/knowledge: Selected Interviews and Other Writings, 1972-1977. New York: Pantheon Books.

Foucault, Michel. 1984. "Nietzsche, Genealogy, History." In The Foucault Reader, edited by Paul Rabinow. New York: Pantheon Books, 76-100.

Foucault, Michel. 2010. The Birth of Biopolitics: Lectures at the Collège de France, 1978-79 (trans. Burchell G). Basingstoke: Palgrave Macmillan.

Fox, Jonathan. 2015. Political Secularism, Religion, and the State, A Time Series Analysis of Worldwide Data. Cambridge: Cambridge University Press.

Gaffney, Adam. 2017. To Heal Humankind, The Right to Health in History. London and New York: Routledge.

Glaser, Eliane. 2016. “Is Digital Culture Responsible for Post-Truth Politics?" Open Transcripts October 29. Acceded January 24, 2018, http://opentranscripts.org/transcript/post-truthpolitics/.

Göle, Nilüfer. 2010. “Manifestations of the Religious-Secular Divide: Self, State, and the Public Sphere." In Comparative Secularisms in a Global Age, edited by Linnell E. Cady and Elizabeth Shakman Hurd, 41-53. New York: Palgrave.

Graeber, David and Thomas Piketty. "Soak the Rich." The Baffler 25, July, Accessed December 21, 2017, https://thebaffler.com/odds-and-ends/soak-the-rich.

Guénin-Paracini, Henri, Yves Gendron, and Jérémy Morales. 2014. “Neoliberalism, crises and accusations of fraud: a vicious circle of reinforcing influences?" Qualitative Research in Accounting \& Management 11(4): 317-356. 
Habermas, Jürgen. 2008. Between Naturalism and Religion: Philosophical Essays. Cambridge: Polity Press.

Harrington, Austin. 2007. "Habermas and the 'Post-Secular Society'." European Journal of Social Theory 10(4): 543-60.

Harsin, Jayson. 2015. "Regimes of Posttruth, Postpolitics, and Attention Economies." Communication, Culture \& Critique 8(2): 327-333.

Harvey, David. 2010. The Enigma of Capital and the Crises of Capitalism. Oxford: Oxford University. Hayek, Friedrich A. 1945. "The Use of Knowledge in Society." American Economic Review 25(4): 51930.

Hayek, Friedrich A. 1952. The Sensory Order, An Inquiry into the Foundations of Theoretical Psychology. London: Routledge and Kegan Paul.

Hayek, Friedrich A. 2011 [1960]. The Constitution of Liberty. Chicago: University of Chicago Press. Hayek, Friedrich A. 1967. "The Theory of Complex Phenomena." In Studies in Philosophy, Politics and Economics. London, Routledge and Kegan Paul, 22-42.

Hayek, Friedrich A. 1989. “The Pretence of Knowledge." The American Economic Review 79(6): 3-7. Hayek, Friedrich A. 2005. [1944]. The Road to Serfdom. London: Routledge.

Hewitt, Marsha Aileen. 2014. Freud on Religion. London: Routledge.

Hurd, Elizabeth Shakman. 2004. "The Political Authority of Secularism in International Relations," European Journal of International Relations 10(2): 235-62.

Hurd, Elizabeth Shakman. 2017. Beyond Religious Freedom: The New Global Politics of Religion. Princeton: Princeton University Press.

Joseph, Jonathan. (2013). "Resilience as Embedded Neoliberalism: A Governmentality Approach." Resilience: International Policies, Practices and Discourses, 1(1), 38-52. Klein, Naomi. 2007. The Shock Doctrine: The Rise of Disaster Capitalism. London: Penguin. Konings, Martijn. 2014. “Hoodwinked by Hayek." Journal of Cultural Economy 7(4): 527-531. 
Konings, Martijn. 2016. "Governing the System: Risk, Finance, and Neoliberal Reason." European Journal of International Relations 22(2): 268-288.

Lynch, Cecelia. 2011. "Religious Humanitarianism and the Global Politics of Secularism." In Rethinking Secularism, edited by in Craig Calhoun, Mark Juergensmeyer and Jonathan VanAntwerpen (eds) Oxford: Oxford University Press, 204-24.

Mavelli, Luca. 2017. "Governing the Resilience of Neoliberalism through Biopolitics." European Journal of International Relations, 23(3), 489-512.

Mavelli, Luca. 2018. "Citizenship for Sale and the Neoliberal Political Economy of Belonging." International Studies Quarterly 62(3): 482-493.

McCutcheon, Russell T. 2007. "'They Licked the Platter Clean', On the Co-Dependency of the Religious and the Secular," Method and Theory in the Study of Religion 19(3): 173-99.

Miguez, Nestor, Joerg Rieger, and Jung Mo Sung. 2009. Beyond the Spirit of Empire: Theology and Politics in a New Key. London: SCM Press.

Mirowski, Philip. 2013. Never Let a Serious Crisis Go To Waste: How Neoliberalism Survived the Financial Meltdown. London: Verso Books.

Moreton, Bethany. 2009. To Serve God and Wal-Mart. Harvard: Harvard University Press.

Nichols, Tom. 2017. "How America Lost Faith in Expertise: And Why That's a Giant Problem." Foreign Affairs. 96: 60-73.

Peck, Jamie, Nik Theodore, and Neil Brenner. 2010. "Postneoliberalism and its Malcontents." Antipode 41(s1): 94-116.

Petito, Fabio and Pavlos Hatzopoulos, eds. 2003. Religion in International Relations: The Return from Exile. New York: Palgrave Macmillan.

Petrella, Ivan. 2008. Beyond Liberation Theology: A Polemic. London: SCM Press.

Pope Francis. 2013. "Apostolic Exhortation Evangelii Gaudium of the Holy Father Francis to the Bishops, Clergy, Consecrated Persons and the Lay Faithful on the Proclamation of the Gospel in Today's World," Vatican. Accessed March 20, 2017, http://www.vatican.va/evangeliigaudium/en/files/assets/basic-html/page1.html. 
Racy, Gustavo. 2016. "Walter Benjamin's Capitalism as Religion, Is there Any Chance for Freedom." Heathwood Journal of Critical Theory 1(3), 84-97.

Rulyova, Natalia and Hannah Westley. 2017. "Changing News Genres as a Result of Global Technological Developments: New News Genres." Digital Journalism 5(8): 986-1005.

Sandal, Nukhet A. and Patrick James. 2011. "Religion and International Relations theory: Towards a Mutual Understanding." European Journal of International Relations 17(1): 3-25.

Scherer, Matthew. 2013. Beyond Church and State: Democracy, Secularism, and Conversion. Cambridge: Cambridge University Press.

Schmidt, Vivien A., and Mark Thatcher, eds. 2013. Resilient Liberalism in Europe's Political Economy. Cambridge: Cambridge University Press.

Snyder, Jack L., ed. 2011. Religion and International Relations Theory. New York: Columbia University Press.

Stiglitz, D. Joseph. 2009. "Moving Beyond Market Fundamentalism to a More Balanced Economy." Annals of Public and Cooperative Economics 80(3): 345-360.

Stone, Jon. 2016. “Nearly Half of Britons Believe Vote Leave's False ' $\mathrm{f} 350$ Million a Week to the EU' Claim." The Independent, June 16. Accessed October 2, 2017, http://www.independent.co.uk/news/uk/politics/nearly-half-of-britons-believe-vote-leavesfalse-350-million-a-week-to-the-eu-claim-a7085016.html 16 June 2016.

Stout, Jeffrey. 1981. The Flight from Authority: Religion, Morality, and the Quest for Autonomy: Notre Dame, IN: University of Notre Dame Press.

Taylor, Charles. 2007. A Secular Age. Harvard: Harvard University Press.

The Independent. 2016. "Donald Trump Declares 'I love the Poorly Educated' as He Storms to Victory in Nevada Caucus." February 24. Accessed October 2, 2017, http://www.independent.co.uk/news/people/donald-trump-declares-i-love-the-poorlyeducated-as-he-storms-to-victory-in-nevada-caucus-a6893106.html.

Thomas, Scott. 2005. The Global Resurgence of Religion and the Transformation of International Relations: The Struggle for the Soul of the Twenty-First Century. London: Palgrave. 
Viner, Katharine. 2016. “How Technology Disrupted the Truth.” The Guardian, July 12. Accessed October 3, 2017, https://www.theguardian.com/media/2016/jul/12/how-technology-disruptedthe-truth 12 . July 2016.

Walker, Jeremy and Melinda Cooper. 2011. "Genealogies of Resilience from Systems Ecology to The Political Economy of Crisis Adaptation." Security Dialogue 42(2): 143-160.

Weber Max. 1991 [1919]. "Science as a Vocation." In From Max Weber, Essays in Sociology, eds. Gerth, Hans H. and C. Wright Mills. Oxford: Oxford University Press, 129-157.

Weber, Max. (1991 [1915]) “Religious Rejections of the World and Their Directions," in Hans H. Gerth and Charles Wright Mills (eds), From Max Weber, Essays in Sociology, Oxford: Oxford University Press.

Weber, Max. 2003 [1905]. The Protestant Ethic and the Spirit of Capitalism, translated by Talcott Parsons. New York: Courier Dover Publications.

Worley, Will. 2016. “Donald Trump Inspired Brexit Campaign Because Facts Don't Work, Says Leave Founder Arron Banks." The Independent, June 30. Accessed October 5, 2017, http://www.independent.co.uk/news/uk/home-news/brexit-news-donald-trump-leave-eucampaign-facts-dont-work-arron-banks-lies-referendum-a7111001.html. 